\title{
CORPORATE HUMAN RIGHTS RESPONSIBILITY AND MULTINATIONALITY \\ IN EMERGING MARKETS - A LEGAL PERSPECTIVE FOR CORPORATE GOVERNANCE AND RESPONSIBILITY
}

\section{First author details and bio:}

Sascha-Dominik Bachmann, LL.D (University of Johannesburg, South Africa), is Associate Professor in Law and the University of Bournemouth. He was educated in Germany (LudwigMaximilians-Universität (LMU) München), South Africa (Stellenbosch University and University of Johannesburg) and the United Kingdom (University of Portsmouth). He was a Lieutenant Colonel in the German Army Reserve and served as a peacekeeper in the Balkans (Kosovo) on three occasions. Prior to completing a LL.M at Stellenbosch University, he was admitted as a German Rechtsanwalt (attorney at law) at the High Court of Munich. His particular research interest are in the fields of Human Rights Litigation, Historical Justice Litigation, Holocaust/Shoa, Terrorism, Law of Armed Conflict, Hybrid Threats and holistic responses to new 21st century security threats. He can be contacted at the Executive Business Centre EB405, Bournemouth University, 89 Holdenhurst Road, Bournemouth, BH8 8EBTelephone: (+44) (0)1202 968746. E-mail: sbachmann@bournemouth.ac.uk

\section{Second and corresponding author details and bio:}

Vijay Pereira, $\mathrm{PhD}$, is a Senior Lecturer of International and Strategic HRM and Leader in Knowledge Services (Human Capital Development) in the Organisation Studies and HRM group at the Portsmouth Business School, University of Portsmouth, UK. He holds six academic qualifications, has published in journals such as the Journal of World Business, International Studies of Management \& Organization, Culture \& Organisation, International Journal of Indian Culture \& Business Administration, etc. He has also contributed to several book chapters. His previous experiences have been in consulting and industry. He is also the Area/Associate editor (OB/HRM) of the Journal of Asia Business Studies (JABS). He can be contacted at the Centre for Organisation Research and Development (CORD), Dept. of Organisation Studies and Human Resource Management, University of Portsmouth, Richmond Building, Portland Street, Portsmouth, Hants, UK- PO1 3DE. Telephone: $(+44)$ (0)2392 844815. E-mail: vijay.pereira@port.ac.uk 


\title{
CORPORATE HUMAN RIGHTS RESPONSIBILITY AND MULTINATIONALITY \\ IN EMERGING MARKETS - A LEGAL PERSPECTIVE FOR CORPORATE GOVERNANCE AND RESPONSIBILITY
}

\begin{abstract}
This 'perspective' paper highlights the evolving concept and idea of Corporate Human Rights Responsibility (CHRR) under international law. The paper thus aims to rectify the scarcity of such a notion within the existing frameworks, and its related significance to other concepts of corporate responsibility and governance. On 11 June 2011, the United Nations Human Rights Council endorsed the 'Guiding Principles for Business and Human Rights' as a new set of guiding principles for global business designed to provide a global standard for preventing and addressing the risk of adverse impacts on human rights linked to business activity. This paper develops and builds upon the emerging concept of CHRR in the context of Emerging Market Multinationality (EMM), by proposing that multinational corporation (MNCs) be more proactive in taking on board CHRR within their corporate governance (CG) and corporate social responsibility (CSR) agendas, so as to avoid future risks of being sued and taken to court. This paper thus aims to use concepts of and alternatives under international law of establishing CHRR, which reflect on existing legislative and political initiatives like the above cited business principles as well as the failed 'Norms on the Responsibilities of Transnational Corporations and Other Business Enterprises with Regard to Human Rights' of 2003. Based on related initiatives such as CSR and good $\mathrm{CG}$ practice, this article further calls for a holistic approach, which combines the existing elements and which is to be borne by a multitude of stakeholders, i.e. consumers, employees to executive directors. The current literature suggests paucity and underrepresentation of research on the legal facets of human right responsibilities on the part of MNCs in emerging economies such as India. The 'ghost' of the Bhopal tragedy twenty seven years ago in India still haunts us and has resurfaced with Dow Chemicals, then Union Carbide, who was responsible for the tragedy, also having sponsored the 2012 London Olympics, and gained more bad press, than good. This study thus specifically looks at India, through the 'unique', chronological and time-line (longitudinal) case of Bhopal, to elucidate our concept of CHRR.
\end{abstract}

Key Words: India; Bhopal case; Corporate Human Rights Responsibility; Corporate Social Responsibility; Good Corporate Governance; Business Guidelines 


\subsection{INTRODUCTION}

This paper develops and builds upon the notion of an emerging concept of 'corporate human rights responsibility' (CHRR) in the context of emerging market Multinationality (EMM). We position CHRR in this paper as an evolving nonbinding notion which does not follow clear legal and management parameters as such. However we propose that MNCs be more proactive in taking on board CHRR within their corporate governance and CSR agendas, so as to avoid future risks of being sued and taken to court. We thus contribute through a CHRR framework later in the paper (Figure 1 below).

We define the notion of CHRR as evident today in international law and corporate governance and responsibility. Thus, in this paper we broadly define CHRR as a notion where corporations are legally responsible for human rights violations initiated by them, and also where they are alleged for complicity and collusion in serious violations of international human rights. We principally portray the practical case study of Bhopal in the context of our definition of CHRR, alongside other international legal case studies, both historical and contemporary.

On 11 June 2011, the United Nations Human Rights Council endorsed the 'United Nations Guiding Principles for Business and Human Rights' (UNGP) as a new set of guiding principles for global business designed to provide a global standard for preventing and addressing the risk of adverse impacts on human rights linked to business activity (Miretski \& Bachmann, 2012; Bachmann, 2010). Previously, Corporate Social Responsibility (CSR) and CHRR have been examined in terms of their 'coherence', 'consistency' and 'operationisation' by the United Nations Secretary General's Special Representative for Business and Human Rights, Professor John Ruggie (McCorquodale, 2009). Research in this area has mostly looked at human rights as a dimension of CSR, nonbinding soft law and the 'blurred' lines between legal, ethical and/or non-legal categories (Mayer, 2009). However, the management implications and consequences, especially in the context of an evident impunity gap for MNCs for their alleged complicity in Human Rights violations committed in the developing world is largely missing. Further, the concept is also best explained mainly through a case study, which would elucidate our concept of CHRR. Hence, though globalization has transformed the way business and work is conducted, the question of corporate management and human rights remains under researched. Emerging economies such as India, a prominent BRICS (referring to the acronym of Brazil, Russia, India, China 
and now South Africa since April 2011) economy has surged ahead recently, largely aided by inward foreign direct investment (FDI), through mainly outsourced Western service work (Pereira and Anderson, 2012; Pereira and Malik, 2013; Pereira and Kalokoti, 2014). We have thus chosen the Bhopal case from India, an emerging economy, to explain our concept of CHRR.

Over the years, globalization and its impacts have been widely debated for their pros and cons. It has been evaluated along the lines of constituting a new form of economic and social freedom. Positive arguments revolve around the phenomena encouraging better connections in a more open world that would improve peoples' lives by making new products and ideas universally available, breaking down barriers to trade and democratic institutions, resolving tensions between old adversaries, and empowering greater number of people (Friedman, 1999; 2006). Originally, many leaders in the West supported the advent of a new world order through free trade and political cooperation (Friedman, 1999; 2006). By the late 1990s however, there was widespread criticism growing. The term globalization was used increasingly to express concern about the consequences of global change for the well-being of various groups, the sovereignty and identity of countries, the growing disparities among peoples, and the health of the environment (Hirst, 1997). Politicians critical to America's and the West's global influence and activists opposed to the inequities of oppressive global capitalism have now begun to portray globalization as dangerous. More recently, two contentious areas have fuelled these globalization arguments. The first is the increased use of 'offshore outsourcing' by multinational firms across the developed world, and the second, the increase in cross-border human migration (Pereira and Anderson, 2012; Pereira and Malik, 2013). Globalization has thus become an issue in a wide-ranging global debate.

Further, many authors attribute the dynamics of globalization to the pursuit of material interests by dominant states and multinational companies that exploit new technologies to shape a world in which they can flourish according to rules they set (e.g. Wallerstein, 1999). Here, a crucial question arises: to what extent these MNCs' strategic and governance rules include or reflect on Human Rights and Fundamental Freedoms? An alternative view suggests that globalization is rooted in an expanding consciousness of living together on one planet, a consciousness that takes the concrete form of models for global interaction and institutional development that constrain the interests of even powerful players and relate any 
particular place to a larger global whole (see for example Robertson, 1992). However, would this always translate into best Human Rights practice?

Hence from a socio-economic angle there is still much that is needed within the area of Corporate Human Rights, especially within the context of increased international business, internationalisation or globalization (see Coicaud et al, 2003 for an overview). To add to this, and as argued above, there have been various 'economist' commentators arguing for and against globalization (e.g. Stiglitz, 2004, Bhagwati, 2004). The recent and ongoing financial crisis has increased the need for 'protection' and 'rights' of individuals and societies that are vulnerable. We then argue that from a CSR and CG perspective it will make good business sense to accommodate the legal dimension of CHRR within MNCs strategic and governance structures, something that is largely missing to date. The current literature suggests a paucity and underrepresentation of the notion and the legal facets of human right responsibilities on the part of Western and emerging market MNCs in emerging economies such as India. The 'ghost' of the Bhopal tragedy twenty seven years ago in India still haunts us and has resurfaced with Dow Chemicals, then Union Carbide, who were responsible for the tragedy, and who sponsored the 2012 London Olympics. This paper elucidates the above aspects through illustrating the above case in India in the wider context of CHRR and thus adds to the emerging knowledge in this area.

There are two aims of this paper. First, to discuss the need to close the impunity gap of Western and emerging market MNCs' complicity in Human Rights violations committed in the developing world in the context of governance, economic, legal, social, voluntariness and philanthropic areas. Second, we identify the accountability gap and highlight the consequences for 'governance' not being proactively involved and engaged in this area. In doing so, this paper will reflect on past and contemporary concepts and alternatives under international law of establishing CHRR, which draw from existing legislative and political initiatives like the above cited business principles as well as the failed Norms on the Responsibilities of Transnational Corporations and Other Business Enterprises with Regard to Human Rights of 2003. The article will chart the following structure: first, we introduce the notion of CHRR as a legal precursor to corporate civil litigation, within its global context. We then move on to discuss how we develop this distinctive notion of CHRR, by juxtapositioning human rights within corporate governance and social responsibility and in 
the process draw a conceptual framework (Figure 1 below). The manuscript then discusses the 'unique' and 'longitudinal' case (Yin, 2009) study on Bhopal, India, before a discussion ensues, linking previous litigation on human rights, after which conclusions are drawn.

\subsection{THE NOTION OF CORPORATE HUMAN RIGHTS RESPONSIBILITY AS A LEGAL PRECURSOR TO CORPORATE CIVIL LITIGATION}

Civil litigation against aiders and abettors of international terrorism before US Federal Courts (Bachmann, 2012) and the just concluded litigation in the Kiobel case before the US Supreme Court (Bachmann, 2012 and Bachmann \& Frost, 2012) have highlighted the important contribution the evolving notion of corporate responsibility for Human Rights violations can play. The notion of Human Rights Responsibility reflects on the idea of corporations being active bearers of Human Rights duties and the potential they have to be active and/or aiding and abetting Human Rights perpetrators.

The growing role of MNCs in the context of transnational business activities over the last 50 years $^{1}$ has also led to an increase in reports of alleged corporate collusion in gross human rights atrocities, which were either committed by state organs of a repressive state, militia or paramilitary groups ${ }^{2}$ (see Bachmann, 2010 for an overview). Subsequently, well publicized transnational human rights lawsuits before US federal courts took place. ${ }^{3}$ Whilst these lawsuits were directly linked to corporate business conduct in the developing world (with a particular focus on exploitation industries) and often falling within the wider scope of the above mentioned "historical justice claims" litigation such as the two Holocaust lawsuits and the recent Apartheid case, other examples of corporate collusion in present day human rights violations followed: that of corporate responsibility for acts of international terrorism, most notably since "9/11". To put this notion and the evolving jurisprudence in an emerging market context, a major case from one of the world's largest and fastest growing economies, namely India, the world's largest industrial disaster, the Bhopal gas tragedy (1984) in India, is discussed in more detail later.

The United Nations recognised a potential correlation between MNCs' business operations and the potential for human rights violations. A general notion has emerged at the international level that corporate human rights violations can lead to corporate accountability with the possibility of victims' rights to redress, including a financial remedy and reparation ${ }^{4}$ Non-binding rules on good corporate conduct ${ }^{5}$ such as the failed Draft Norms on the 
Responsibilities of Transnational Corporations and Other Business Enterprises with Regard to Human Rights ${ }^{6}$ of 2003 serve as an example (Miretski \& Bachmann, 2012). These rules effectively represent a future set of non-voluntary norms for corporations. Despite being adopted by the Sub-Commission on the Promotion and Protection of Human Rights, they failed to be recognised by its main organ, the now abolished UN Human Rights Commission (as the predecessor to the Human Rights Council was known until 2006). The general response to these norms was contentious and they were even labelled as "exaggerated claims and conceptual ambiguities". 7

Since 2006, the Special Representative of the Secretary General and Harvard professor Ruggie, has been working to transform the rather vague policy framework of "Protect, Respect and Remedy" of the UN into binding principles of "Business and Human rights". The final product, the Guiding Principles on Business and Human Rights: Implementing the United Nations "Protect, Respect and Remedy" Framework came into force in 2011. This framework makes detailed recommendations to corporations for respecting human rights, pending their eventual implementation by states signatory to these principles ${ }^{8}$ (Miretski \& Bachmann, 2012), thereby further substantiating our argument that it would make good business sense for MNCs to be proactive by incorporating CHRR agendas in their corporate governance structures. Failure to reflect on these developments and the failure to respond by incorporating the key concepts of human rights and CHRR adherence and compliance in existing CG structures and codes will eventually cause financial liability to organisations.

In summary here, it is submitted that while there exists an evolving notion of corporate Human Rights responsibilities at the international level, there is no regime of hard law and possible enforcement mechanisms yet in place. The need for establishing such binding regimes of CHRR is apparent, especially before the backdrop that MNCs may want to avoid lawsuits arising from breaches of international law as well as the potential damage to corporate image and mission. A powerful example are the ongoing miner strikes in South Africa, which have spread to industries other than mining and seen examples of spreading violence (with shooting of 44 miners by SA Police in the Marikana incident of 2012); these instances of volatile wild strikes have already cut the industrial output of the country's mining by half and it is estimated that it will take SA up to ten years to recover from its negative impact on the economy as such $^{9}$. Consequently one can state that the prospect of corporate human rights litigation, the existing concepts of existing notions of CHRR, as well 
as the opinion of the consumer market may already today impact on business conduct, comparable to CSR and CG, which is now discussed below.

\subsection{THE JUXTAPOSITION OF HUMAN RIGHTS WITHIN THE SPHERES OF CORPORATE GOVERNANCE AND SOCIAL RESPONSIBILITY}

Following Gillan and Starks (1998) corporate governance (CG) here is defined as the system of laws, rules, and factors that control how organisations operate. Further, most researchers interpretation of CG mechanisms are both internal and external to these organisations. Traditionally, known as the 'balance sheet' model, internal stakeholders within CG would include the board of directors and the management, whereas, external stakeholders within CG include shareholders and debt holders. However Gillian (2006: 385-385) developed this further and divided internal governance into five basic categories: The Board of Directors (and their role, structure, and incentives); Managerial Incentives; Capital Structure; Bylaw and Charter Provisions (or antitakeover measures); and Internal Control Systems. Similarly he divides external governance into five groups: Law and Regulation, specifically federal law, self-regulatory organisations, and state law; Markets 1 (including capital markets, the market for corporate control, labour markets, and product markets); Markets 2, emphasizing providers of capital market information (such as that provided by credit, equity, and governance analysts); Markets 3 - focusing on accounting, financial and legal services from parties external to the firm (including auditing, directors' and officers' liability insurance, and investment banking advice), NS; and Private Sources of External Oversight, particularly the media and external lawsuits. We argue here that positioning the concept of CHRR within any or all of these governance categories would mean proactively and strategically being prepared for future eventualities arising from potential lawsuits and litigation but also from collective strike action taken to highlight existing shortcomings of economic and social parity.

Similarly, corporate social responsibility (CSR) too has evolved over the decades. Previously Carroll (1983: 604) defined it as:

'....CSR involves the conduct of a business so that it is economically profitable, law abiding, ethical and socially supportive. To be socially responsible...then means that profitability and obedience to the law are foremost conditions to discussing the firm's ethics and the extent to which it supports the society in which it exists with contributions of money, time and talent. Thus, CSR is composed of four parts: economic, legal, ethical and voluntary or philanthropic'. 
Carroll rightly lists the legal dimension here. Dahlsrud (2006:4) however argues that CSR definitions over the years have been framed on five dimensions i.e. environmental, social, economic, stakeholder and voluntariness. However, interestingly, the legal dimension is not specifically mentioned, but is meshed within the other dimensions, mainly social and voluntariness. In this context we argue that CHRR is already 'enmeshed' with all dimensions of CSR and hence inseparable. Economically, it will be good practice to include the notion of CHRR within the wider framework of CSR as it makes good business sense to avoid a bad image resulting from future human rights claims. Within the other CSR dimensions of ethics, voluntariness and philanthropy too, corporate human rights responsibilities are already recognised and often entwined.

Overall, the legal dimension of CHRR is largely recognised. The post-1945 era saw a dynamic promotion and creation of human rights and their legal instruments. ${ }^{10}$ The newly established United Nations (UN) - directly reflecting on the gross human rights atrocities which were committed during the Second World War - made the promotion of human rights one of its main objectives: Article 1(3) of the UN Charter of 1945 stipulates as one explicit purpose, common to all member states, the achievement of 'international co-operation [...] in promoting and encouraging respect for human rights and for fundamental freedoms for all without distinction as to race, sex, language, or religion.' This resolve led to the adoption of the 1948 Universal Declaration of Human Rights (Universal Declaration) by the General Assembly. The Universal Declaration acknowledges human rights as non-derivable, universal principle of international law (Bachmann, 2008). Consequently, a sophisticated UN system of monitoring, promoting and eventually protecting human rights has been developed under the various UN charter and treaty instruments. ${ }^{11}$ This 'backbone' of UN human rights protection is supplemented by other regional human rights protection systems, in Africa, the Americas, Europe, and to a lesser extent in the Arab world. International human rights law ultimately means, in the words of the Inter-American Court of Human Rights (IACtHR), ${ }^{12}$

[...] The objective of international human rights law is not to punish those individuals who are guilty of violations, but rather to protect the victims and to provide for the reparation of damages resulting from the acts of the States responsible.

While the notion of human rights has become a globally recognised principle, state complicity in such violations, together with a lack of state compliance with the duty to enforce these human rights at the domestic and international level is often questionable in 
terms of their effectiveness. The main reasons for this failure are, firstly, that compliance with human rights obligations still largely fall within the discretion of respective states with the direct consequence that only states with a highly-developed human rights law culture comply with obligations; secondly, the lack of supplementary human rights provisions, which establish individual and non-state actor responsibility, exempts the actual perpetrators of human rights violations from accountability; ${ }^{13}$ and, thirdly, a universal forum for addressing violations such as a Universal Human Rights Court as a body supplementary to the International Court of Justice (ICJ) or as a new independent judicial organ is lacking (Bachmann, ibid). The inclusion of non-state actors as human rights protectors and stakeholders, such as MNEs and MNCs, might require a doctrinal shift in the way we think about the protection of human rights. Such an inclusion of human rights addressees at the horizontal level (as opposed to the traditional concept of state versus individual, also referred to as vertical human rights protection) is already taking place as the above mentioned 'Ruggie' guidelines show. We therefore argue that the future challenge and objective remains to align corporate business conduct with the protection of human rights in order to address the realities posed by a growingly multi-polar world of global business and human rights awareness. This we propose can only be achieved through a blend of corporate governance and social responsibility.

The correlation between global business and the discussed notions of corporate governance and social responsibilities, and human rights within their respective frameworks can be best demonstrated by the following illustration, i.e. figure 1:

\section{Insert Figure 1 about here}

Next, our notion of (CHRR), in the context of emerging market Multinationality (EMM) is demonstrated and narrated through the case study on Bhopal, India. Before we move to the case, it is necessary to reflect on CG in this second fastest growing economy, India.

\subsection{CORPORATE GOVERNANCE IN INDIA}


India has a diverse historical context. Largely influenced by the British rule, it has an established judiciary and other institutions such as the bureaucracy etc. However, postindependence in 1947, India towed the socialist route and had more in common with China and Russia, during its initial growth period, with the state in control of major industries (see review by Machold and Vasudevan, 2004). According to Tricker (2012), it was as late as 1992 when the Securities and exchange Board of India was created by the parliament and a first CG code was published in 1998 by the confederation of Indian Industries (CII). Modern Indian organisations who compete globally have set themselves high CG standards. The Indian Companies Act of 1956 was amended in 1999 and 2000 to improve shareholders rights and to give powers to audit committees.

Also in the case of India, CG is still in its infancy stage and corruption, nepotism etc. are rampant. Thus, India has a democratic governance model as it shares the same problems of any emerging and evolving market economy. Furthermore in India, though it has a wellestablished judiciary, it is slow, bureaucratic and time consuming. These aspects will be brought out in the case study later.

With reference to the above framework, the human-rights issues and 'corporate human rights responsibility' (CHRR), in the context of emerging markets compounds the above discussed issues. Moreover, these issues have not been seen through the legal dimension lens, and to date remain unaddressed. This study thus specifically looks at India, through the chronological and time-line case, to elucidate our concept.

\subsection{CASE STUDY METHODOLOGY}

The case study component of the research design is grounded in the approach set out by Yin (2009). He defines a case study as "an empirical inquiry that ... investigates a contemporary phenomenon in depth and within its real-life context when ... the boundaries between phenomenon and context are not clearly evident" (Yin, 2009:18). A key issue with case study research is the selection of the case(s). Yin (2009:47-49) identifies a range of types. First a 'critical case', wherein a well formulated theory is tested. Second, a 'unique case', which, because of its rarity portrays something different to the norm. Third, a 'representative' or a 'typical case' where the objective is to capture the circumstances and conditions of an everyday or commonplace situation. Fourth, a 'revelatory case' where the investigator has an

opportunity to observe and analyse a phenomenon that was inaccessible previously. Fifth, a 
'longitudinal case', where a single case is studied at two or more different points in time and change over time in certain conditions is observed. Any single 'case' may involve more than one unit of analysis. This research portrays both an overlapping 'unique' and 'longitudinal' case. This is discussed through the following section titled 'lessons from the Bhopal case'.

\subsection{LESSONS FROM THE BHOPAL CASE}

'The 1984 gas leak in Bhopal was a terrible tragedy that understandably continues to evoke strong emotions even 27 years later', this statement in 2012 from the 'horse's mouth', Union Carbide Corporation's (UCC) website (Union Carbide Corporation website, 2012) is an understatement. UCC was one of the first U.S. companies to invest in India. The Bhopal plant was built in the late 1970s. Its ownership included a fifty percent share by UCC. The plant produced pesticides for use in India's agricultural sector. On the $3^{\text {rd }}$ of December 1984, shortly after midnight, methyl isocyanate (MIC) gas leaked from a tank at the Bhopal plant, killing 15,000 people and injuring at least 500,000 others. Millions were left sick and the affected passed on the harmful effects of the gas to the next generations, a legacy which is continuing to this date. Arguably, this is widely accepted as the world's worst and largest industrial disaster to date. In 1985 the Government of India (GOI) enacted the Bhopal Gas Leak Disaster Act, which enabled the GOI to act as the legal representative of the victims in litigation claims arising directly from or being related to the Bhopal disaster. In April 1985, UCC offered a mere $\$ 7$ million as interim relief to the victims, before the U.S. District Court, an offer which was rejected by the GOI. Throughout 1988, arguments and appeals took place before domestic Indian courts regarding compensation for the victims. In November 1988, the Supreme Court of India recommended to the GOI and UCC to reach a settlement. Consequently, the court thereafter outlined a final settlement including all Bhopal litigants, amounting to a total of $\$ 470$ million, to be paid by March 31, 1989. Both the GOI and UCC then accepted the court's direction. However, in 1990, the Supreme Court of India heard several petitions by activists throughout the year aimed at overturning the settlement, which was a separate parallel litigation case. In December 2005, the U.S. Federal District Court dismissed two of the three claims, and brought in the non-related litigation of Janki Bai Sahu versus $U C C$; this litigation was for damages for alleged personal injuries from exposure to contaminated water and remediation of the former Bhopal plant site and its original docket was filed in November 2004. In August 2006 the U.S. Court of Appeals upheld dismissal of the Bano case. The Second Circuit Court of Appeals in New York upheld the dismissal of the 
remaining claims in the case of Bano vs. UCC, thereby denying plaintiffs' motions for class certification and claims for property damages and remediation of the Bhopal plant site by Union Carbide. In March 2007 a group of Indian citizens file a New Class Action Lawsuit in a New York Federal Court: Jagarnath Sahu et al vs. UCC and the then (1984) Chief Executive of UCC Warren Anderson, seeking damages to clean up six individual properties allegedly polluted by contaminants from the Bhopal plant, as well as the remediation of property in sixteen colonies (areas) adjoining the plant. The suit was then halted pending the decision in the appeal case in Janki Bai Sahu. In May 2008 the Second Circuit Court of Appeals referred the Janki Bai Sahu case back to the U.S. District Court in Manhattan for limited further activity based strictly on procedural grounds. The Second Circuit did not discuss the merits of the case or the merits of the trial judge's ruling of dismissal. Thereafter, in February 2009, the U.S. Federal District Court in New York rejected a mediation request as requested by the plaintiffs in the Janki Bai Sahu litigation. Finally, in February 2010 the court rejected a motion to dismiss the case and a further motion to disqualify the judge from hearing the case. In April 2011 the UCC submitted a motion for summary judgment in the Sahu case, pending decision.

While the civil litigation arising from the Bhopal disaster seems to stall, there had been at least some results in respect to individual criminal responsibility. On June 7, 2010, eight corporate officers stood trial in a domestic Indian criminal case for their complicity in the Bhopal case: the accused, including the then Indian Chairman of Union Carbide, Keshub Mahindra, were convicted and sentenced to two years imprisonment each and fined a mere US\$ 2,124. All eight were released on bail shortly after the verdict. In May 2011, the Supreme Court of India asked the Group of Ministers (GoM) on Bhopal to decide expeditiously on the disposal of 350 tonnes of toxic waste of the Bhopal Gas tragedy. On August 28, 2012, a district and session court in India upheld the 2010 verdict of a lower criminal trial court in the Bhopal gas tragedy case while dismissing the country's premier investigating agency, the central bureau of investigation's (CBI's) petition seeking re-trial and enhancement of sentence awarded to former UCC officials. Additionally, the revision petition seeking enhancement of sentences under the new section of 304-II of India Penal Code (IPC), which provides for a maximum sentence of 10-year imprisonment, was rejected by the same district and sessions court. Ironically in 2012, UCC, which has now become Dow Chemicals, was one of the main sponsor of the London Olympic Games, sparking national and 
international criticism and protests, with the Indian Olympic contingent threatening a boycott. However, nothing substantial was achieved and the stalemate continues.

\subsection{DISCUSSION- GLOBALIZATION AND CORPORATE CIVIL RESPONSIBILITY AS AN EMERGING NOTION OF MULTINATIONAL CORPORATE ACCOUNTABILITY}

The above Bhopal case study example has shown the interdependency and interconnectivity of both, criminal and civil responsibility, as well as their respective remedies, and shown the necessity of such a dual accountability approach, when dealing with cases of corporate human rights violations. It further portrays the frustrations of reaching a timely decision and closure in terms of reaching its logical end.

To date, there exists only one domestic jurisdiction where such a holistic approach of hybrid accountability can be found: the USA, where multi-billion US-\$ damages in a civil lawsuit supplement potential criminal proceedings against company directors. Also known as US human rights litigation, US federal law allows for litigation instituted against the individual and corporate human rights violator, aider and abettor of such violations as well as international terrorism (Bachmann \& Frost, 2012; Miretski \& Bachmann 2012; Bachmann 2012). This form of litigation developed over the last 30 years. In 1980 the 2nd Circuit District Court heard the seminal Filartiga v Pena- Irala case, where acts of (state instigated) torture committed outside the territory of the USA and involving two non-US citizens as both victim and perpetrator, was brought as an action before US federal courts. The court established its jurisdiction in this instance based on the Alien Torts Claims Act (now being referred to as the Alien Tort Statute (ATS)), a statute from 1789 which had hardly been used for nearly 220 years (Bachmann \& Frost, 2012; Bachmann 2012).

The scope of US human rights litigation is remarkably wide in the context of parties concerned. Individuals have the right to initiate legal action against other individuals, judicial persons and in some instances, even states, as perpetrators of human rights violations. Human rights litigation under the ATS provides one of the few opportunities for natural persons as litigants to seek redress for human rights violations committed in an extraterritorial context, in a country other than the one where the violation has taken place. ATS adjudication allows actions to be brought against individual defendants, both state and non-state, for certain human rights and terrorism delicts, torts respectively, and an increasing number of lawsuits 
against MNCs for their complicity in human rights atrocities committed by repressive regimes in developing countries, as well as their complicity in international terrorism. The last decade has seen a number of cases brought against corporate aiders and abettors of human rights violations. Cases were brought against corporations for their alleged complicity and collusion in serious violations of international human rights law, including crimes against humanity, war crimes and torture as well as alleged violations of other human and fundamental rights as protected under various civil, political, economic, social and cultural rights treaties. The case Doe I vs. Unocal concerned allegations of corporate complicity in forced labor and torture, Wiwa v Royal Dutch Petroleum Company referred the alleged involvement of the Royal Dutch/Shell oil group in human rights abuses in Nigeria, leading to the 1995 torture and murder of the environmental and community activist Ken Saro-Wiwa. Other such examples include a case on alleged corporate complicity in the commission of war crimes committed by Papua New Guinean Security Forces in Sarei v Rio Tinto.

Interesting and potentially relevant in the context of corporate human rights responsibility are three particular cases, which highlight the potential liability of corporate aiding and abetting: the two Holocaust lawsuits and the still ongoing Apartheid lawsuit. In the case In re Holocaust Victim Assets Litigation (also known as the Swiss Gold Bank case) nearly 900,000 victims and relatives filed a class action suit against the three largest Swiss banks in 1996, alleging that Swiss banks had breached international and national law by "knowingly retaining and concealing the assets of Holocaust victims, accepting and laundering illegally obtained Nazi loot and transacting in the profits of slave labor." The case led to a \$ 1.25 billion settlement in 1998. (Bachmann \& Frost, 2012; Miretski \& Bachmann, 2012; Bachmann 2012) The second Holocaust case, the so called Nazi slave labour case, was brought as another class action against DAX-listed German corporations for the use of forced 'slave' labour during World War II by the defendant corporations themselves and/or their legal predecessors. This highly politicized case led to a settlement in 1999 when the defendant corporations and the German government agreed to establish a jointly funded $\$ 5$ billion foundation for compensating the surviving victims of Nazi slave labor. The Foundation 'Remembrance, Responsibility and the Future' was established in August 2000 for the compensation of victim groups.

Such litigation for "historical justice claims" saw further -often unsuccessful litigation taking place in the USA: most notably the so called "Brooklyn slave labour case", In re African-American Slave Descendants Litigation, which was modeled after the 
successful Holocaust lawsuits, but which was unsuccessful due to a failure to prove causation for the actions of the defendants and also due to a lack of additional support by pressure groups.

The case of Kiobel before the US Supreme Court threatens to severely limit the applicability of US judicial fora for acts of corporate complicity/ collusion in the commission of international crimes and gross human rights violations. This will also seriously impact on the choice of the USA as a judicial forum par excellence to adjudicate such human rights violations. In April of 2013, the US Supreme Court decided the case of Kiobel, which concerned a claim under the ATS against Royal Dutch Petroleum and Shell, alleging that they were aiders and abettors of acts of serious human rights violations such as extrajudicial killings, crimes against humanity and acts of torture, by Nigerian security forces. In a 5 to 4 split decision the Court decided to limit the scope of its extraterritorial applicability in the context of the enforcement of international norms. This judgment effectively questions whether other cases which were brought under the ATS since 1980 would be successful today (Bachmann \& Frost, 2012).

Whether this will lead to a future exclusion of such lawsuits against corporate aiders who do not commit the crime/ tort itself will have to been seen (as the court did not comment on another question raised, namely if corporations as legal persons can in principle be complicit as aider and abettors in such violations of international law). Any such momentary judicial setback for the adjudicability of corporate human rights violations before the courts of the world's economic superpower will have to be seen before the backdrop of the fast evolving notion of human rights litigation, as exemplified by this autumn's decision by a UK High Court to allow a group of elderly Kenyans to sue the British government for alleged crimes against humanity (Engelhart, 2012). Hence we argue that the notion of 'Corporate' Human Rights Responsibility (CHRR) is here to stay.

\subsection{CONCLUSIONS}

The role and impact of globalization in developing countries is seen to be fuelled by foreign direct investment, whereby it boosts their economic performance by endowing them with new skills, new technologies, and new jobs, all of which increase their standard of living. Detractors however contend that MNCs too often demand special treatment for their export businesses, push back on environmental regulations, seek to avoid taxes, take advantage of cheaper labour costs and at the same time resist more costly labour market rules in the 
countries where they invest. For more than a generation the world's economy has been on a seemingly unstoppable march toward tighter economic, political, and social alignment as people, goods, and capital became ever more mobile. The current scenario is witnessing globalization being driven by decisions by countries like India to open their economies to the world (Pereira and Kalakoti, 2014), but without its fair share of human rights challenges, as was seen through the case study. Human rights issues have to date still been elusive and at time illusionary to the vast majority of stakeholders affected by MNCs in these countries. Were MNCs to find themselves exposed to a significantly higher risk of being successfully prosecuted, in terms of corporate criminal as well as civil responsibility respectively, for their collaboration in such human rights abuses, negative publicity as well as negative share value could be the result. If such a scenario became a real risk possibility, then MNCs might rationally decide that their duties to their shareholders required them to withdraw from and avoid operating in any country whose human rights record has caused concern. However former employees and even consumers and customers as well as other stakeholders of those MNC branches might take a different view - in fact, they might even reflect that the now disinvesting MNCs used to be one of their best hopes for improving human rights in that country. For example, proponents such as Bhagwati (2004) suggests that levels of FDI were positively associated with quality of working conditions in developing countries.

Bhagwati (2004) questions if MNCs supplement the good that results from their economic activities with additional CSR programmes. These he argues could be voluntary codes (specific obligations) for what MNCs should do; or mandatory codes (diverse in nature) for what MNCs should not do; or other 'social norming' - e.g. UN Global Compact for MNCs to sign up to. De George (1998) argues that international business has far fewer 'background institutions' to control or guide corporate behaviour and hence much more has to depend on the moral judgement of these MNC management. He proposes MNC 'Code of Conduct', which includes: First, to do no intentional direct harm i.e. Act so as to benefit the host country; no utilitarian trade-offs; second, the good of the host country may not be the same as the good of the current regime; third, respect the human rights of workers, consumers and others in the host country; fourth, promote the development of just background institutions, within the host country and internationally; and fifth, respect the laws of the host country as well as its culture and values, provided these do not violate human rights or impose immoral laws. In sync, our proposal of CHRR would be seen as a practical and amicable solution. 
To conclude, even though there has been a recent popularity of the concept of globalization in academic debates, there is a dearth of research on its implications on the 'human-rights' issues of various stakeholders such as employees, management, consumers, customers, clients, suppliers, governments, economies, geopolitics, non-governmental bodies etc. In other words the implication of 'globalization' on 'human rights' of stakeholders is lacking. Moreover there is a deficiency in research into management's role in organisations effected by these human rights issues and challenges due to globalization, especially through the lenses of corporate governance and CSR. Hence this paper attempted to provide evidence and shed light on some of the views and debates in the literature and on the impacts of globalization on the workplace, through an important case study. It attempts to contribute to the debate by researching human rights issues and implications in multinational organizations. In doing so it aims to illuminate our understanding of what is actually happening to organizations, its management, corporate governance and CSR strategies as a result of the wider term 'globalization'. These developments affect CHRR, despite the recent setbacks in finding a binding normative approach on the issue, as the failed Norms of 2003 and the watered down Ruggie guidelines exemplify. With the prospect of seeing a potential reversal of the US litigation approach against the corporate aider and abettor for indirect liability, the overall prospect of seeing a binding normative regime on CHRR developing is rather dim. The potential risk and costs stemming from potential CHRR breaches warrants a dogmative rethink: does CG and CSR allow taking such a risk? Or does the corporate world not need a preemptive approach? We propose that this research would hence represent substantial contributions to this learning process and better understanding from the perspective of business and management, corporate governance and social responsibility and human rights. 


\section{ENDNOTES}

${ }^{1}$ P Blumberg, 'Asserting human rights against multinational corporations under United States law: Conceptual and procedural problems' (2002) 50 American Journal of Comparative Law, at 493. "In the modern global economy, the largest corporations conduct worldwide operations. They operate in the form of multinational corporate groups organized in "incredibly complex" multi-tiered corporate structures consisting of a dominant parent corporation, sub holding companies, and scores or hundreds of subservient subsidiaries scattered around the world. The 1999 World Investment Report estimated that there are almost 60,000 multinational corporate groups with more than 500,000 foreign subsidiaries and affiliates"

${ }^{2}$ See e.g. O. De Schutter Transnational Corporations and Human Rights (Hart Publishing, Oxford, Portland, OR 2006); A Ramasastry and R Thompson, 'Commerce, crime and conflict - Legal Remedies for Private Sector Liability for Grave Breaches of International Law', (Fafo Institute of Applied International Studies 2006), retrievable at http://www.fafo.no/pub/rapp/536/536.pdf (last accessed at 28-09-2011) Appendix A, 29ff (last accessed at 28-09-2011).

${ }^{3}$ Cf John Doe I v. Unocal Corp., 403 F.3d 708

4 Ibid and UN News "Corporate Law Firms Join UN-led Initiative on Business and Human Rights", $28 \quad$ January 2009 at http://www.un.org/apps/news/story.asp?NewsID=29693\&Cr=business \&Cr1=Human+rights.

5 See e.g. guidelines on good corporate practice and corporate social responsibility as listed at the University of Minnesota's Human Rights Library, retrievable at http://www1.umn.edu/humanrts/business/codes.html.

6 U.N. Doc. E/CN.4/Sub.2/2003/12/Rev.2 (Aug. 26, 2003). See Martin-Ortega, "Business and Human Rights inConflict" in 22.3 Ethics \& International Affairs 2008, 273-283.

${ }^{7}$ Ruggie in his initial 2006 Report of the Special Representative of the Secretary-General on the issue of human rights and transnational corporations and other business enterprises, UN Doc.E/CN.4/2006/97.

8 UN Doc A/HRC/17/31 of 21 March 2011; for the full text of the Guiding Principles, see UN Human Rights Council, Report of the Special Representative of the Secretary-General on the issue of human rights and transnational corporations and other business enterprises, John Ruggie - Guiding Principles on Business and Human Rights: Implementing the United Nations "Protect, Respect and Remedy" Framework at http://www.ohchr.org/documents/issues/business/A.HRC.17.31.pdf (last visited Jul 12, 2011).

${ }^{9}$ See for e.g. Matthew Davies, Strikes keep pounding South Africa's economy, BBC News at http://www.bbc.co.uk/news/business-20041370

${ }^{10}$ See e.g. Cassese International law (2008) $350 \mathrm{ff}$, Dugard International law - a South African perspective (2005) 308-309.

${ }^{11}$ The legal development of human rights protection in the UN followed essentially three doctrinal influences: the western doctrine from 1945 to the mid-50s, the socialist doctrine from the mid-50s to the mid-70s and thirdly, from the mid-70s until today, the doctrine of developing countries, see Cassese (n 1) 354-356.

${ }^{12}$ See the Velasquez Rodriguez decision of 1988 Ser C No 4 reported in (1988) 9 Human Rights Law Journal 212 par 134.

${ }^{13}$ Nowak., Introduction to the international human rights regime (2003) 289. 


\section{REFERENCES}

Ahluwalia, M. S. (2006). India's Experience with Globalization. The Australian Economic Review, 1-33.

Bachmann, S. (2008). Civil Responsibility for Gross Human Rights Violations - the need for a global instrument. Monograph published by Pretoria University Law Press.

Bachmann, S. (2010). Human Rights and Global Business: the evolving notion of corporate civil responsibility, 1 Indian Yearbook of International Law and Policy. Launch edition, May 2010 .

Bachmann, S. (2012). Bankrupting Terrorism: The Role of US Anti-Terrorism Litigation In the Prevention of Terrorism and other Hybrid Threats - A Legal Assessment and Outlook, 33 (2) Liverpool Law Review.

Bachmann, S. \& Frost, T. (2012). Colonialism, Justice and the Rule of Law: a Southern African and Australian narrative, 45 (2) De Jure.

Bhagwati, J. (1993). India in Transition. Oxford: Oxford University Press.

Bhagwati, J. (2004). In defense of Globalization. New York: Oxford University Press.

Buckley, P. J., \& Casson, M. (1974). The Future of the Multinational Enterprise. New York : Holmes \& Meier.

Carroll, A. B. (1983). Corporate social responsibility: Will industry respond to cutbacks in social program funding? Vital Speeches of the Day, 49, 604-608.

Coicaud, J-M, Doyle, M. \& Gardner, A-M. 2003 (eds) The Globalization of Human Rights, Tokyo: The United Nations University Press.

Dahlsrud, A. (2006). How Corporate Social Responsibility is defined: an Analysis of 37 Definitions. Corporate Social Responsibility and Environmental Management, 15 (1), 1-13.

De George, R T. (1998). Business Ethics, Prentice Hall

Dicken, P. (2010). Global Shift - Mapping the Changing Contours of the World Economy. London: Sage. 
Engelhart. K., (2012). Rule Britannia: Empire on Trial, World Policy Institute, World Policy Journal, Winter 2012 Issue: "Africa's Moment". Sage Publication. December 2012 29: 94105.

Forsgren, M., Holm, U. \& Johanson, J. (2007). Managing the Embedded MNC: A Business Network View. Cheltenham: Edward Elgar.

Friedman, T. (2006). The World is Flat. London: Penguin Books.

Friedman, T. L. (1999). The Lexus and the Olive Tree. New York: Anchor Books.

Friedman, T. L.(2005). It's a Flat World, After All. The New York Times .

Ghoshal, S., \& Bartlett, C. A. (1988). Creation, Adoption, and Diffusion of Innovations by Subsidiaries of Multinational Corporations. Journal of International Business Studies , 19 (3), 365-388.

Gillan, S. (2006). Recent Developments in Corporate Governance: An Overview, Journal of Corporate Finance, Volume 12, Issue 3, June 2006, Pages 381-402.

Gillan, S. \& Starks, L. (1998). A survey of shareholder activism: motivation and empirical evidence. Contemporary Finance Digest, 2: 10-34.

Hirst, P. (1997). The global economy - myths and realities. International Affairs , 73 (3), 409425.

Machold, S., Vasudevan, A.K. (2004) Corporate governance models in emerging markets: the case of India. International Journal of Business Governance and Ethics, 1(1): 56-78.

Mayer, A.E. (2009). Human Rights as a Dimension of CSR: The Blurred Lines Between Legal and Non-Legal Categories. Journal of Business Ethics, 88:561-577.

McCann, P., \& Mudambi, R. (2005). Analytical differences in the economics of geography: the case of the multinational firm. Environment and Planning A , 37, 1857- 1876.

McCorquodale, R. (2009). Corporate Social Responsibility and International Human Rights Law. Journal of Business Ethics, 87:385-400.

Meyer, K. E., Mudambi, R., \& Narula, R. (2011). Multinational Enterprises and Local Contexts: The Opportunities and Challenges of Multiple Embeddedness. Journal of Management Studies , 48 (2), 235-252.

Miretski, P., and Bachmann, S. (2012). 'Global Business and Human Rights - The UN "Norms on the Responsibility of Transnational Corporations and Other Business Enterprises 
with Regard to Human Rights" - A Requiem', with (Hebrew University Jerusalem), 17 Deakin Law Review.

Narula, R. (2003). Globalization and Technology: Interdependence, Innovation Systems (Vol. 23). Cambridge: Polity Press.

Nayar, B. R. (2007). Social stability in India under Globalization and Liberalization. India Review, 133-164.

Pandey, M. T. (2011). Globalization and social transformation in India: Theorising the transition. International journal of Sociology and Anthropology, 253 - 260.

Pereira, V., and Malik, A. (2013) East is East? Understanding aspects of Indian culture(s) within organisations: a special issue of Culture and Organization Volume 21, issue 5 (2015). Culture and Organization, 19 (5). pp. 1-19. ISSN 1475-9551

$10.1080 / 14759551.2013 .848634$

Pereira, V., and Kalakoti, R. (2014, in press) Liberalisation of the Indian retail sector: an examination of macro level HR implications and challenge. International Journal of Indian Culture and Business Management. pp. 1-19. ISSN 1753-0806

Pereira, V., and Anderson, V. (2012) A longitudinal examination of HRM in a human resources offshoring (HRO) organization operating from India. Journal of World Business, 47 (2). pp. 223-231. ISSN 1090-9516 10.1016/j.jwb.2011.04.009

Robertson, R. (1992). Globalization: Social Theory and Global Culture. London: Sage.

Rudra, N. (2008) Globalization and the Race to the Bottom in Developing Countries . Cambridge: Cambridge University Press.

Rugman, A. M. (2003). Regional strategy and the demise of globalization. Journal of International Management, 9 (4), 409-417.

Stiglitz, J. E. (2002). Globalization and its discontents. London: Allen Lane.

Tricker, R. I. (2012). Corporate Governance - principles, policies and practices. Oxford University Press.

Union Carbide Corporation (2012) website http://www.unioncarbide.com/bhopal last visited 1st September 2012.

Wadhva, C. D. (2004). India trying to liberalise economic reforms since 1991. in J. Rolfe (ed) Asia Pacific: A Region in Transition, Honolulu: Asia Pacific Center for Security Studies. 
Wallerstein, M. (1999). Wage-setting institutions and pay inequality in advanced industrial societies. American Journal of Political Science, 43 (3), 649-80.

Yin, R. (2009). Case study research: Design and methods. London: Sage.

(C)

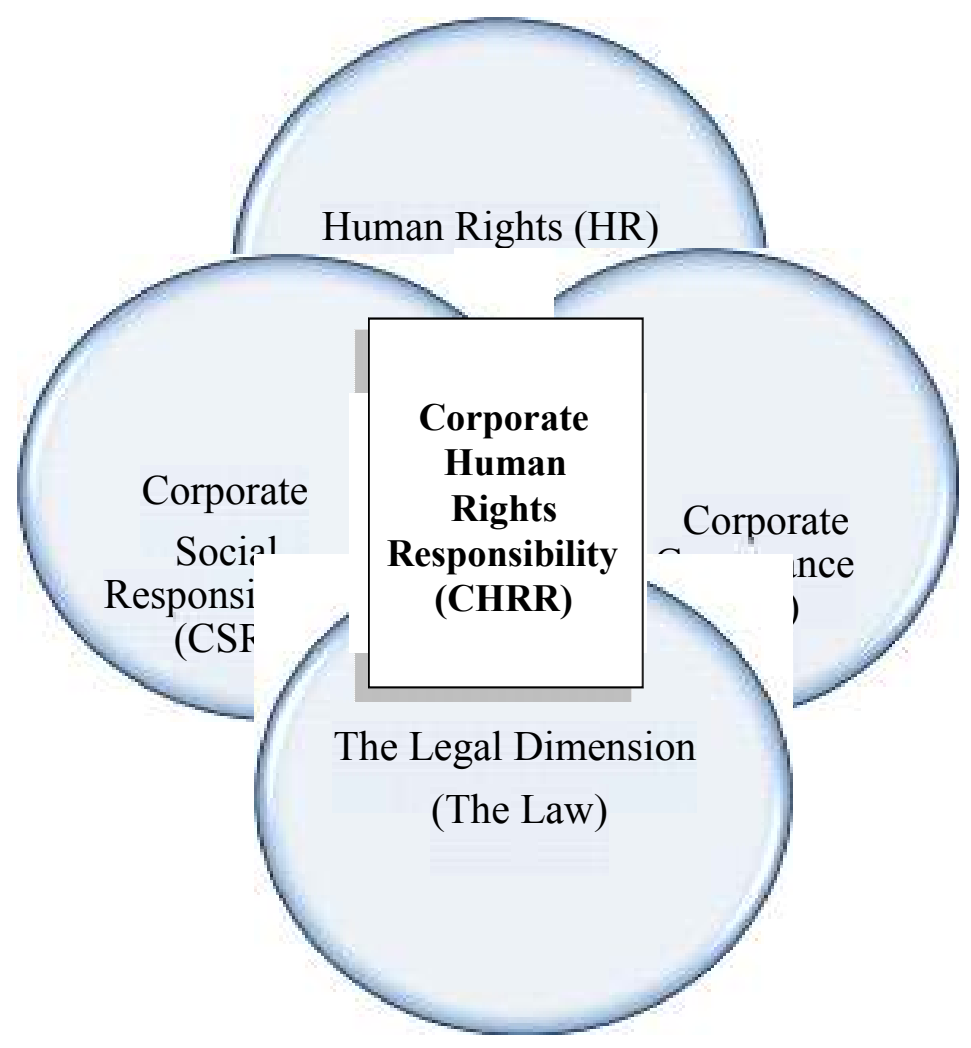

Figure 1: Juxtaposition of human rights within corporate governance and social responsibility 